\title{
The Challenges of Struggling Writers: Strategies That Can Help
}

\author{
Michael Dunn (1)
}

check for

updates

Citation: Dunn, M. The Challenges of Struggling Writers: Strategies That Can Help. Educ. Sci. 2021, 11, 795 https://doi.org/10.3390/educsci 11120795

Academic Editor: Ian Hay

Received: 1 September 2021

Accepted: 29 November 2021

Published: 7 December 2021

Publisher's Note: MDPI stays neutral with regard to jurisdictional claims in published maps and institutional affiliations.

Copyright: (C) 2021 by the author. Licensee MDPI, Basel, Switzerland. This article is an open access article distributed under the terms and conditions of the Creative Commons Attribution (CC BY) license (https:// creativecommons.org/licenses/by/ $4.0 /)$.
Department of Special Education and Literacy, Washington State University Vancouver, Vancouver, WA 98686, USA; dunnmi@wsu.edu

\begin{abstract}
Writing is a necessary skill in our technological world. Many people have a mobile device that they use for e-mailing, social media, as an alarm clock to start the day, reading the news, searching for information, ordering food, managing transportation (e.g., monitoring traffic, accessing public transit), or for relaxing pursuits, such as watching a movie or listening to music. While these tasks are natural and almost effortless for numerous people, many students struggle with composing longer prose, especially for academic tasks. The 2021 U.S. National Assessment of Educational Progress for Writing, for example, indicates that as many as 75\% of students cannot write at a basic level. In this article, the author discusses recent examples from the professional literature about why writing can be a challenge for students, what is involved in writing assessment, how we can help students improve their writing skills, and how we can promote technology as part of the instruction and learning processes.
\end{abstract}

Keywords: writing; technology; strategy instruction; assessment; teacher professional development

\section{Introduction}

Technology has become a virtual necessity for people in our culture [1,2]. Almost everyone has some type of smartphone or mobile device, as well as either a laptop or desktop computer [3]. We search and review written content from all types of sources (e.g., news, weather, banking information), and use these devices to create our own written content, such as a response to someone else or notes for ourselves. We can use technology tools to phone people, have video conversations, text message, create videos, edit pictures, share images, and produce written texts for school assignments or work tasks. With voiceto-text software, we can speak to our technology tools and have them do the (virtual) typing for us, and the device's screen reader can then read the text back to us for editing and proofing [4]. Yet, there are many people who find literacy tasks to be a challenge, e.g., $[5,6]$, and technology tools alone have not yet proven themselves to be an immediate solution.

The results of the U.S. National Assessment of Educational Progress for Writing [7] from the 2017 assessment, which had fourth- and eighth-grade students use mobile devices to answer writing prompts, indicate that $75 \%$ of students could not compose text at a basic level, and the results for students from diverse backgrounds were even worse. It is important to note that about 7.7\% of the U.S. student population (aged 3-17 years) has a learning disability [8], and about $12 \%$ of the U.S. K-12 public school population has a disability of some type [9]. The U.S. NAEP-Writing results indicate that about 75\% of students struggle with writing, which could imply that the $12 \%$ of students who have a learning or other type of disability is much larger. This article offers some suggested solutions, on the basis of the professional literature, to answer these questions: (1) What are the challenges that students with writing difficulties face? (2) What is involved in writing assessments, such as the U.S. National Assessment of Educational Progress and the SmarterBalanced Assessment Consortium? (3) What can students, teachers, schools, and parents/families do to promote writing improvement? (4) What can be done to promote technology as part of the instruction and learning process to help students who 
struggle with writing? In commenting on these questions, the author's framework included: students, aged seven to adulthood (grade 2 to university), who are on either side of the decision point for special education; students who struggle with writing; and students with a learning disability in dysgraphia (writing). These students are very similar in terms of their academic needs (e.g., difficulties with focusing on a task; storing key information in the memory, such as the spelling of words; or being an avid reader) and the strategies (e.g., step-by-step instruction, mnemonic strategies) from which they can benefit [10]. This article offers educators a discussion of some of these central issues pertaining to writing instruction and student learning in order to contemplate how teachers, parents, schools, and school districts may consider their own students' strengths and weaknesses with writing, as well as what types of strategies could be added to help them improve their skills. Writing has a renewed emphasis with the growth in the use of mobile devices, keyboarding, changes in curriculum standards (e.g., the implementation of the Common Core in the United States), and, in recent decades, a more knowledge-based economy that focuses on science, technology, engineering, and math (STEM), with their argumentative-based writing cultures.

Technology can be defined in at least two ways: as a device or as a service [11]. The Individuals with Disabilities Education Improvement Act (IDEA) [12] defines an "assistive technology device" as "any item, piece of equipment, or product system, whether acquired commercially off the shelf, modified or customized, that is used to increase, maintain or improve functional capabilities of a child with a disability (20 U.S.C. 1401(1)). The IDEA defines an "assistive technology service" as, "any service that directly assists a child with a disability in the selection, acquisition or use of an assistive technology device ... such as ... interventions, therapies or services." This author views technology as both devices and services (e.g., intervention programming). Students need teacher interaction, teacher modeling, student practice, and teacher feedback to develop independence in using technology for core skills, such as for writing.

Furthermore, the author seeks to define how writing can be a challenge for many people, how schools and assessment consortiums tend to assess writing, how technology is a part of that process, and how technology tools can help students improve their writing skills. These are significant and huge topics to address. This article is not a definitive set of ideas or a framework. There is always more to add. Yet, this article can help frame the conversation among students, teachers, parents, families, school districts, and government policymakers to help better address the needs of these students and improve their writing skills.

\section{The Challenges That Students with Writing Difficulties Face}

Writing is a complex and multifaceted process that can pose challenges for many children [13]. A student's potential to improve and master the writing process can be attributed to their family and literacy practices at home, a willingness to improve, and the learning environment at school. There is a genetic component to learning disabilities [14]. Landi and Perdue reviewed studies $(n=35)$ that applied the neuroimaging genetics approach to learning disabilities in reading and developmental language disorders, as the genes with known neurodevelopmental function are linked to brain abnormalities in function and structure. The authors concluded that their results highlight the complex nature of cognitive disabilities, such as in reading and language. Yet, the authors comment that their results illustrate that genetics is just one part of the brain's role in the existence of a disability. Advances in neuroimaging may help, as well as magnetic resonance spectroscopy (MRS) and advanced DNA sequencing methods. Other factors are at play in causing students to have disability characteristics, such as in writing. Socioeconomic status and family literacy practices (e.g., being read to in early childhood, talking about story books) can promote students' success with literacy tasks, such as writing [15]. Mendive and colleagues analyzed the home language and literacy environments of 1425 Chilean mothers from low socioeconomic households to measure their children's early literacy growth from 
prekindergarten to kindergarten. The children whose mothers read and talked about texts to their children, and who were taught letters, demonstrated higher vocabulary and letter knowledge.

As children grow older and the demands of literacy tasks increase in school, the struggles of students may stem from physiological reasons (e.g., inefficient memory mechanisms in the brain and the motor movement of the arms and hands). Student writing challenges may originate from an inefficient executive functioning system: the ability to focus their attention to make sense of meaningful incoming information, making sense of it with what they already know in their long-term memory, and then applying their working memory to use that new information to expand their knowledge and long-term memory [16,17]. Berninger and colleagues analyzed the attention/executive functions and language learning in fourth- to ninth-grade students with and without learning disabilities. There was a correlation between a student's having had a previous attention deficit hyperactivity (ADHD) diagnosis and handwriting ability. The parents' ratings for inattention correlated with the students' written language skills. Cordeiro and colleagues completed a longitudinal analysis (hierarchical regression) of the inhibitory control, working memory, cognitive flexibility, and planning of second-grade Portuguese students $(n=116)$ across a six-month intervention timeline. In the fall, students completed tasks for writing and executive functioning skills, and, in the spring, students only performed writing tasks. The results indicate that working memory and planning helped to better improve the effects on the text quality of students six months later, as compared to gender, reasoning, and transcription skills. At school, writing instruction typically begins in earnest in second grade (age 7 years), when students are to create more elaborate connected texts, moving beyond learning words and their meanings and spellings, seeing and reading them in story books, and writing single sentences. The role of teachers in the instructional choices, the use of curriculum materials, the monitoring of student progress, the offering of strategy instruction to help students who struggle with writing, and the assessment of the students' writing skills across the different genres are fundamental to the opportunities of students to improve [18].

To be a good writer, one has to spend time reading [19]. In doing this, a student's willingness, desire, personal initiative, and commitment come into play [20]. Menon asked children, aged 7-10 years $(n=240)$, to complete questionnaires about their attitudes towards managing math tasks. Question topics included: demographics, IQ, reading ability, working-memory capacity, attitudes about math, math interest, and self-perceived ability. The parents rated their children's behavioral and emotional characteristics, anxiety about math, and general anxiety. A portion of the student sample $(n=47)$ completed MRI brain scans while completing arithmetic problems. The students' math performances correlated with a positive attitude towards math, even after statistically controlling for IQ, working memory, math anxiety, general anxiety, and general attitude toward academics. While children with poor attitudes towards math rarely performed well, students with strongly positive attitudes demonstrated a range of math achievements. If a person wants to improve in any skill, they can benefit from a positive attitude-a drive to change their skill level. The best of the tools and materials to make or fix something will not matter much if there is no willingness to learn how to use them, practice, and become good at using them. Attitude and commitment are the glue that holds all of the ideas, strategies, and devices together to help students improve their writing skills.

For students who struggle with writing, reading high-quality texts provides a means to observe how good writing is organized and demonstrated in words, sentences, and paragraphs [21]. If decoding is a challenge for the student, e-readers are really helpful tools for this purpose [22]. Students should choose texts that are of interest to them across different genres. Story books, novels, magazine articles, and informational texts about a news story are some examples. If the student is expected to write a specific genre of text for a university course, for example, it is best that they first spend time reading and reviewing high-quality examples of that genre. After reading a text, the student should 
think about what the text aimed to say and discuss the ideas and the text's structure with someone else. The student could also learn more about the ideas on the web or from other sources at a library, for example. Developing familiarity with the genre of text, a lab report's components, the types of content and sentences, and how research questions are posed and answered all help the student to apply these ideas in their own writing and improve this skill over time.

With an ongoing practice of reading, the task of managing a writing assignment can seem less daunting. Regular time spent reading and analyzing texts (e.g., daily, or even a few times each week) helps a student to have more confidence in developing their own drafts of texts [23]. Alkhamra and colleagues analyzed the writing challenges of undergraduate students $(n=28)$ on the basis of their own self-reported ratings and those of their instructors $(n=25)$ at the University of Jordan. The results identified fives aspects of writing as challenges for these students: handwriting, sentence structure, vocabulary, spelling, and written expression. Both participant groups had similar and high agreement about the students' written language challenges. Alkhamra and colleagues stated the need for universities and instructors to offer strategies and tools to help students improve their writing skills. For example, it helps if the instructor offers a rubric or a description of the required components, as well as some exemplars of high- and low-quality examples [24]. Discussing these exemplars in class with the instructor can help students make their texts even better.

After reading and reviewing texts, the student can then begin thinking of a topic and components for their own writing [25]. Each student will have their own ideas and practices to outline their ideas. De Smedt and colleagues completed a study about this topic. The authors employed structural equation modeling analyses with the questionnaire ratings of fifth- and sixth-graders $(n=1577)$ about their writing self-efficacy, motivation, and use of strategies. The authors also apportioned the students into two groups to complete assessments of either informational or narrative writing. The authors concluded that teachers should consider the characteristics of each learner when providing intervention programming to address the motivational and cognitive writing challenges of students, such as the planning stage of writing a text. Making notes of each idea can help. Some writers like to use graphic organizers or webs to define key ideas, and then subpoints or examples. This author has found illustrating ideas to be helpful for students who struggle with writing [26]. In a single-subject design study, Dunn and colleagues offered fourth- to fifth-grade students $(n=4)$ the opportunity to illustrate their story ideas on an iPad before generating text. Students found the activity helpful as it offered them the opportunity to think about ideas without being challenged with concurrently spelling words and sentences. The results demonstrated that the students improved their writing content and quality scores by $25 \%$ or more above the baseline levels. Employing technology devices and apps can also help students manage the process of writing. Microsoft's [27] OneNote (a free app for use on any type of device) has numerous features for typing text, writing with a stylus, drawing, and using premade shapes to add to illustrations. A student can access their OneNote app's files on a school computer, their own phone or mobile device, or later, at home on a desktop. Google Docs [28] and Google Keep [29] are two other similar types of apps.

With a topic and outline of ideas, the student can then begin drafting text. This prompts a new level of complexity for the student in the writing process [30-32]. Concurrently, the student needs to manage ideas, text structure (the progression of ideas and events from the beginning to the end), word choice (e.g., using a key word only once in a sentence), spelling, the vocabulary associated with the topic, varying sentence types, paragraphing, punctuation, and grammar. These tasks can illustrate how writing can be a complex process that prompts the need for intervention programming. Gillespie and Graham [31] completed a meta-analysis of 43 studies about writing interventions for grades 1-12 students with learning disabilities. The results included four writing practices as having significant results: strategy instruction, $\mathrm{ES}=1.09$; dictation, $\mathrm{ES}=0.55$; goal setting, $\mathrm{ES}=0.57$; and 
process writing, ES $=0.43$. The authors also found that planning and revising were only effective when paired with instruction.

Writing researchers have suggested a number of frameworks for what to include when promoting the writing development of students. The cognitive-processing model of Flower and Hayes [33] includes planning (idea generation, use of oral language), translation (drafting connected text), and reviewing (revising to produce a finessed final text). Vygotsky's [34] theory of child development encourages the practice of self-talk as it can help students who struggle with writing manage a challenging task, such as idea generation. Dockrell and Arfé [35] suggest four guiding principles for writing instruction: offering students the opportunity to frequently practice writing; acknowledging that writing is a type of personal meaning making (metacognition); offering students systematic formative feedback; and providing students with high-quality examples to emulate in their own writing. Dockrell and Arfé underline the social aspect of writing, as well as the individual and developmental differences of struggling writers. Lin et al., [36] interviewed 28 students from diverse backgrounds in grades $2-8$ about their knowledge of the purposes and forms of writing, the characteristics of good writing/writers, and composing practices. The authors' results indicate that typically achieving writers, versus struggling ones, differed in their length and organization, their application of strategies, as well as their use of terminology/vocabulary. Struggling writers mainly focused on mechanics, spelling, punctuation, capitalization, and penmanship, and they commented on the need for a teacher, parent, or classmate to help identify their mistakes in order to improve their texts. Struggling writers can sense the need to engage in the writing process with others in order to learn and apply strategies to improve their writing skills.

\section{What Is Involved in Writing Assessments}

Assessment is a key feature of any instructional model, including writing [37,38]. An educator needs to determine a student's current level of ability in order to know how to help them improve. Assessing content and quality tends to be the two main aspects of writing that researchers report in their results [39-41]. Content has to do with the genre of the text and whether or not the writer addressed its key elements. For example, Graham and Harris [42] developed the WWW, $\mathrm{W}=2, \mathrm{H}=2$ acrostic for the key questions that a narrative story should include (Where does the story take place? Who is in the story? When does the story take place? What happens? What happens next? How does the story end? How do the characters feel?). For expository writing, such as a lab report, the purpose of the experiment, and the results and discussion, are key components to address. Writing researchers also often include curriculum-based measurement (CBM) [43] results; examples may include the number of words written, the number of words spelled correctly, or the number of correct writing sequences (counting each syntax element of a text, such as a capital letter to begin a sentence, ending it with proper punctuation, etc.).

"Quality" refers to being at the grade level, as well as the complexity or richness of a text. The use of adverbs and adjectives, complex sentences, and writing a virtual painting are some examples of how to take simple ideas and produce a more elaborate or rich text. Both content and quality typically need some type of rubric or scale, with exemplars for scoring texts. Teachers should be monitoring the writing skills of students on a regular basis. For making decisions about student skill levels (e.g., changes in the types of intervention programming, or a change in instructional classroom), Graham et al. [44] analyzed the texts of third-/fourth-grade students $(n=137)$ from diverse backgrounds who participated in the free/reduced lunch program. The authors concluded that the number of texts needed (\#) varied by the writing measure (total number of words [TNW]) (14), the vocabulary diversity (8), and the writing quality (11). How students performed on one assessment did not predict their score on another writing measure. Having an efficient means to score more students across genres could help teachers and students to better monitor writing skills. 
Technology may have a larger role in scoring writing in the future [45]. Researchers are exploring machine scoring: computer algorithms may read portions of text to discern the writer's intent, suggest edits, and produce a leveled score. Fry's [46] readability index uses word (syllable) and sentence lengths to produce a suggested grade-level score for a given text. Writing Mentor is a free Google Docs add-on designed to offer users feedback on their drafts of text. By using natural language processing (NLP) that is based on the research of postsecondary struggling writers, Writing Mentor offers users feedback about the use of sources/evidence, topic development, the coherence of the user's prose, and the application of English conventions. Madnani et al., [47] analyzed user data $(n=1960)$ and concluded that, while users employed all of the tools, their preferred features were (from most to least): grammar errors, the claims feature, and topic development. McCurry [48] found that human scorers were more reliable than machine scoring, especially where writers can choose the topic and create longer prose. For most researchers, the typical assessment of writing methods entails training two people as scorers, with a rubric and some exemplars for each level, having them practice and discuss feedback, and then scoring the dataset, and meeting to discuss divergent scores so as to attain $100 \%$ agreement [49].

The U.S. National Assessment of Educational Progress for Writing [7] employs the human-scoring method in its large assessment system. Once the scorers are trained, their scoring is monitored by supervisors. Using two scorers per text provided for inter-rater reliability in the $70 \%$ range. Using one trained scorer with supervision rendered reliability in the $60 \%$ range. More review (e.g., by two scorers) and discussion would provide more integrity in the results. The Smarter Balanced Assessment Consortium [50] process includes rubrics and exemplars per each scoring level. The process of Smarter Balanced is similar to that of the NAEP in that "each student's essay is hand-scored analytically using data points that align directly with state assessment rubrics" [51].

Assessing writing can also be challenging as there is a definite component of subjectivity that is part of the process, even with two trained scorers reviewing each text independently and then convening to resolve divergent ratings [52]. This is likely true of all types of writing assessment. Fry's [46] readability index, as an example of a writingassessment technology, may be one exception, but it lacks the component of accounting for overall readability and idea progression, which a human can assess. Evanini et al. [53] analyzed the e-rater automated scoring software for the 2011 Test of English as a Foreign Language (TOEFL) Junior Comprehensive Test. After scoring five texts per participant $(n=3385)$, the human-machine correlation was 0.83, compared to the human-human correlation of 0.90 . These results indicate promise for machine scoring. Replication of these findings, as well as more research across the many genres of writing (e.g., narrative, informational, expository, persuasive, and argumentative) will render a clearer sense of the potential for machine scoring. If machine scoring is to become standard practice, it will need to demonstrate this ability to manage the complexities in writing, such as vocabulary and word choice, sentence formation, text progression (introduction, middle, ending), and relaying an overall message(s), especially in longer texts where the writer chooses the topic [48].

Regardless of the assessment method, it is the teacher's interpretation of the student texts, and their content and quality, that help to inform day-to-day classroom instruction [54,55]. The following should be the focus of assessment: What are the student's areas of weakness in writing? What are their strengths? What can help students improve? It is very motivating to a learner to receive points of praise about their work? This encouragement helps to intrinsically motivate them to work to improve.

\section{Methods for How to Promote Writing Improvement among Students}

As mentioned earlier, to be a good writer, one needs to be reading high-quality texts [19]. Teachers and parents at home should devote time each day (e.g., $30 \mathrm{~min}$ or more) for reviewing high-quality texts with their children, thinking about the text's message, how the author organized the text, the progression of ideas, word choice, etc. Teachers spending 
even a few minutes per day on phonemic awareness activities, for example, can significantly help struggling readers improve [56]. These practices also map well to writing [57] with daily practice, the reviewing and revising of drafts, receiving feedback, etc.

Technology can also be a real help to a struggling writer, who likely is a struggling reader. E-readers can help a student by decoding the text for them, offering a means for the student to read along with the recording, adjust the speed, and review the meanings of unknown words [58]. Troia [22] cited e-readers in a list of evidence-based practices. The concept of helping students who struggle with literacy skills, such as reading and writing, with a technology tool that can decode and voice a text to a student, in lieu of having them decode the text, can be a real help. Merga and Roni [59] analyzed children's ( $n=997)$ data from the 2016 Western Australian Study in Children's Book Reading. The authors sought to determine the children's amount of access to e-readers and their frequency of use, as compared to how often the students read recreational books. The authors found that students having access to a mobile device, which included an e-reader, were still required to act and use the tool. When students choose to do this, their efforts in reviewing high-quality texts could be time well-spent.

When struggling writers demonstrate that they do not know how to manage creating a given genre of text, strategy instruction can really help. Graham et al., [60] completed a meta-analysis of writing interventions. The interventions with the largest effect sizes included: strategy instruction, such as self-regulated strategy development (SRSD); using imagery to illustrate ideas and content before drafting text; peer and adult feedback; and goal setting. The lowest effect sizes included: teaching transcription skills (e.g., create five topic sentences as a written/stand-alone activity) and grammar instruction (e.g., written spelling and punctuation activities).

Self-regulated strategy development (SRSD), the most effective method from Graham et al. [60], has six components. First, the teacher is to review the student's written text to specify their strengths and weaknesses in writing. What type of strategy would help? The teacher should then review the professional literature (e.g., research articles, practitioner journals) and choose one that meets the need of the student. Second, the teacher meets with the student to discuss the purpose in learning a new strategy (e.g., to help improve story-writing skills) and to explain that it can help them to know where to start in doing the task and how to produce a better final copy, which provides for a better grade, as well as skills that they can apply to work and life as an adult. Third, the teacher begins modeling the use of the strategy, and voices aloud all the mental thoughts of a skilled writer (e.g., "I need to open my laptop"; "I need to think about what my writing topic will be"; or "What should I write about in my text?"). This teacher-model text may be short and succinct to address the required components of the genre. The teacher should provide at least three examples of the process. Fourth (guided practice), the teacher asks students to become increasingly more involved in writing and offering ideas in another few rounds of text-making. Fifth (independent practice), the students should be able to manage, at least at a basic level, each of the components of the genre. For a narrative story, the students should be able to write a text that answers all of the WWW, $\mathrm{W}=2$, $\mathrm{H}=2$ questions [42]. Sixth (generalization and maintenance), the teacher can discuss with the students how the strategy they have learned could be applied to other tasks at school or in life. A story-writing strategy could apply to a historical essay about a past event in a famous person's life, for example.

Another instructional model example for struggling writers is cognitive strategy instruction in writing (CSIW) [61,62]. It was designed to help students manage expository writing. By focusing on the structures of expository texts, students can develop their understanding of cause-effect, problem-solution, and comparison-contrast; this can help students with reading comprehension and the composition of expository texts [63,64]. CSIW is similar to SRSD in its sequential steps (e.g., teacher modeling, the teacher's guided feedback to students, and independent practice) [65]. CSIW differs in that the beginning steps are with the whole class, discussing and generating a text as a group. Students then 
draft texts independently, and this is followed by peer feedback. The teacher provides students with "think sheets", with prompts and cues to help students generate more elaborate texts.

Writing researchers have developed cognitive strategy examples, such as those just described, as a learning sequence for students to improve their writing skills. They share the practices of discussing ideas, generating drafts, discussing possible edits, and finessing their prose for a final copy. These practices, paired with the reading and analyzing of highquality/published examples, as well as the use of technology tools, can offer a powerful synergy to help students improve their own writing. A willing, positive, and committed attitude, and taking the time each day to read text, practice writing, and produce written text with keyboarding on a mobile or desktop device can help students become increasingly more productive in generating prose.

\section{Making Technology Tools Part of the Writing Process}

As educators, and as a society that aims to help our children attain grade-level goals, we should continue to make technology tools available to all children. For writing, this includes some type of monitor and keyboard; tablets are great, but a companion keyboard helps with text production [66,67]. Teachers and parents must also model and teach children the potential uses of technology for writing. Daily modeling of these practices to children can really help them to apply the practices of good writers.

A second key task that is needed is the creation of strategy research, with technology tools available to teachers, students, and parents. Currently, research about technology tools is scattered across the Web, often behind fee-based walls that prevent students from benefiting from the help they need. Research and practitioner journals are prime examples. See Table 1 for a list of examples.

Table 1. Resources for Writing Strategies and Web Tools.

\begin{tabular}{|c|c|c|c|}
\hline $\begin{array}{l}\text { Writing Strategy } \\
\text { Resources }\end{array}$ & Type of Resource & Website Link & Open Access Status \\
\hline $\begin{array}{l}\text { Teaching Exceptional } \\
\text { Children }\end{array}$ & $\begin{array}{l}\text { Practitioner journal for teachers, } \\
\text { parents, and students. }\end{array}$ & $\begin{array}{c}\text { https://journals.sagepub. } \\
\text { com/home/tcx (accessed on } 3 \\
\text { December 2021) }\end{array}$ & $\begin{array}{l}\text { Fee subscription required for } \\
\text { online access. }\end{array}$ \\
\hline $\begin{array}{l}\text { Self-Regulated } \\
\text { Strategy Development } \\
\text { (SRSD) }\end{array}$ & Strategy website & $\begin{array}{l}\text { https: } \\
\text { / / srsdonline.org/about-srsd/ } \\
\text { (accessed on 3 December 2021) }\end{array}$ & $\begin{array}{l}\text { Some materials are free with } \\
\text { e-mail signup; some videos } \\
\text { require a paid fee. }\end{array}$ \\
\hline PurdueOWL & $\begin{array}{c}\text { Web tool for help with strategies } \\
\text { to write a text, manage } \\
\text { referencing, etc. }\end{array}$ & $\begin{array}{l}\text { https: / / owl.purdue.edu/ } \\
\text { (accessed on } 3 \text { December 2021) }\end{array}$ & Open access/free \\
\hline Grammarly.com & $\begin{array}{l}\text { Website and browser app to help } \\
\text { with spelling, grammar, } \\
\text { concise text. }\end{array}$ & $\begin{array}{c}\text { https: } \\
\text { / / www.grammarly.com/ } \\
\text { (accessed on } 3 \text { December 2021) }\end{array}$ & $\begin{array}{l}\text { Basic/free option and a } \\
\text { premium paid option with } \\
\text { help for tone, plagiarism, } \\
\text { fluency, etc.; and a business } \\
\text { plan for e-mail, style } \\
\text { guides, etc. }\end{array}$ \\
\hline Google Translate & $\begin{array}{l}\text { A website where the user can } \\
\text { paste text in one language and } \\
\text { have it translated to another. }\end{array}$ & $\begin{array}{c}\text { https: } \\
\text { / / translate.google.com/ } \\
\text { (accessed on 3 December 2021) }\end{array}$ & Open access/free \\
\hline
\end{tabular}

Self-Regulated Strategy Development [59] is an open-source website that describes its steps for teaching a new strategy and shows videos of teacher experiences. More open-source venues are needed for people to find ideas for how to manage writing.

A third component is professional development for educators [68]. While many people use technology in their personal lives for many purposes, and teach themselves how to manage devices and apps, using technology for teaching and learning can be more 
complex. Teachers need regular opportunities to hear about new ideas and discuss them with colleagues in order to implement technology for writing with their own students.

A number of professional organizations provide information, activity, and strategy ideas for writing. Table 2 provides some suggestions.

Table 2. Websites with Instructional and Strategy Ideas for Writing.

\begin{tabular}{cc}
\hline Organization & Weblink \\
\hline National Writing Project & https://www.nwp.org/ (accessed on 3 December 2021) \\
International Literacy Association & https://www.literacyworldwide.org/blog/digital-literacies/teaching- \\
National Council of the Teachers of English & https://ncte.org/ (accessed on 3 December 2021) \\
Association of Writing Programs (AWP) & https://www.awpwriter.org/ (accessed on 3 December 2021) \\
European Literacy Network & https://www.eln.eu/en/ (accessed on 3 December 2021) \\
\hline
\end{tabular}

The National Writing Project, based in the United States, organizes teacher leaders to offer workshops for less-experienced educators to learn about writing. The International Literacy Association has a worldwide membership of 300,000 literacy educators, researchers, and experts from 128 countries. The aim is to help students research and develop arguments, improve their writing skills, and publish texts about topics reflecting their interests. There are online communities for teachers to learn ideas and discuss with other educators. The International Literacy Association has 175 community sites across the United States. The organization offers research publications with content that can be applied by practitioners, offers standards for literacy professionals and postsecondary education programs, provides awards and grants, and advocates for the literacy needs of students, teachers, and parents. The National Council of the Teachers of English, also based in the United States, works to support teachers and students, from public school to university, and face-to-face and online. Through journals, publications, and resources, the organization shares lesson ideas, research, and teaching strategies through its annual convention and other professional learning events. The Association of Writers and Writing Programs advocates for writers, academic programs, and other organizations to help champion diversity and excellence in creative writing. The European Literacy Network focuses on research about writing. The organization offers conferences and workshops at no fee and with the possibility of the attendees receiving grants to pay for travel.

\section{Conclusions}

Writing is a multifaceted process $[16,17]$. Many struggling writers have reading challenges as well [16]. Employing technology tools can help students manage reading, which can help students to improve their writing skills [22]. Reviewing good writing means offering students examples of text, content, and organization that they can employ in their own writing. By adding step-by-step strategies to students' learning, they can become even more independent and skilled at writing. Mnemonic strategy instruction, and a step-bystep sequence in applying a strategy (e.g., SRSD: self-regulated strategy development) [59] are two examples. Technology tools can help students to further improve (e.g., with editing and spelling help). Teachers should have opportunities for professional development in order to learn how to ensure that technology tools, which are constantly evolving, have an even more positive impact on students.

Many students use their technology devices for social and life tasks [1-3], and this can help students have a more positive attitude about using technology to improve their writing skills and assessment results. Educators need to continue to enrich student learning with strategies and technology tools to help them better manage writing. Accessing ideas and resources from professional organizations, which include writing instruction and development, can be helpful for teachers and their students. These types of practices can help students become more successful in education and can encourage them to participate in their community and in adult life. 
Limitations are applicable to this discussion about writing. This article offers example ideas to help students who struggle with writing, strategy instruction, assessment, and technology, yet each of these topics could be the subject of their own literature review. Secondly, with writing being such a multifaceted and concurrent skill (e.g., idea creation, spelling, sentence making, paragraphing, text structure, editing, the various genres of narrative, expository, etc.), no one strategy or tool is likely to resolve the challenges that students face in writing.

Future research could explore how the writing strategies documented in research address the needs of a large numbers of students. If students could read or view strategies online in a shared website with their teacher, and then apply them in their own writing, researchers would have larger sample sizes to compare strategies and technology tools by grade level(s) and student demographics. This research into practice formats via technology could help teachers, students, and parents have more options and ideas to manage writing.

Funding: This research received no external funding.

Data Availability Statement: The content of this conceptual (research-to-practice) manuscript is based on the author's review of the professional literature; the author's own research and findings; and the author's experiences as a public-school teacher for 11 years near Toronto, Ontario, Canada, the last six of which were as a special education and English as a second language teacher.

Conflicts of Interest: The author declares no conflict of interest.

\section{References}

1. United Nations. Technology and Innovation Report 2021. Catching Technological Waves. Available online: https://unctad.org/ page/technology-and-innovation-report-2021 (accessed on 3 December 2021).

2. Davidavičienė, V.; Al Majzoub, K.; Meidute-Kavaliauskiene, I. Factors affecting knowledge sharing in virtual teams. Sustainability 2020, 12, 6917. [CrossRef]

3. Edwards, G. Technology in Everyday Life. 2021. Available online: https://unctad.org/system/files/official-document/tir2020_ en.pdf (accessed on 22 November 2021).

4. di Gregorio, S. Voice to Text: Automating Transcription. In Analyzing and Interpreting Qualitative Research: After the Interview; Vanover, C., Saldana, J., Mihas, P., Eds.; SAGE Publications: Thousand Oaks, CA, USA, 2021; p. 97.

5. Amalia, H.; Abdullah, F.; Fatimah, A.S. Teaching Writing to Junior High School Students: A Focus on Challenges and Solutions. J. Lang. Linguist. Stud. 2021, 17, 794. [CrossRef]

6. Fischer, L.M.; Meyers, C. Determining change in students' writing apprehension scores in a writing-intensive course: A pre-test, post-test design. J. Agric. Educ. 2017, 58, 69-84. [CrossRef]

7. National Assessment of Education Progress-Writing. 2021. Available online: https://nces.ed.gov/nationsreportcard/tdw/ scoring/scoring_within_wri.aspx (accessed on 31 August 2021).

8. Zablotsky, B.; Black, L.I. Prevalence of children aged 3-17 years with developmental disabilities, by urbanicity: United States, 2015-2018. In National Health Statistics Reports, No 139; National Center for Health Statistics: Hyattsville, MD, USA, 2020. Available online: https://www.cdc.gov/nchs/data/nhsr/nhsr139-508.pdf (accessed on 31 August 2021).

9. U. S. Department of Education. 42nd Annual Report to Congress on the Implementation of the INDIVIDUALS with Disabilities Education Act, Jessup, MD: Education Publications Center. 2020. Available online: https://www2.ed.gov/about/reports/ annual/osep/2020/parts-b-c/42nd-arc-for-idea.pdf (accessed on 31 August 2021).

10. Kavale, K. The Feasibility of a Responsiveness to Intervention Approach for the Identification of Specific Learning Disability: A Psychometric Alternative; National Research Center on Learning Disabilities Symposium: Kansas City, MO, USA, 2003.

11. Evmenova, A. Implementation of assistive technology in inclusive classrooms. In Assistive Technology to Support Inclusive Education; Emerald Publishing Limited: Bingley, UK, 2020.

12. Individuals with Disabilities Education Act; 20 U.S.C. § 1400; U.S.; Government Publishing Office: Washington, DC, USA, 2004.

13. Young, N.D.; Bonanno-Sotiropoulos, K. Instructional Strategies to Support the Writing Process for Students with Learning Disabilities as Well as Struggling Writers. In Paving the Pathway for Educational Success: Effective Classroom Strategies for Students with Learning Disabilities; Rowman \& Littlefield Publishers: Lanham, MD, USA, 2018; p. 87.

14. Landi, N.; Perdue, M.V. Neuroimaging genetics studies of specific reading disability and developmental language disorder: A review. Lang. Linguist. Compass 2019, 13, e12349. [CrossRef]

15. Mendive, S.; Mascareño Lara, M.; Aldoney, D.; Pérez, J.C.; Pezoa, J.P. Home Language and Literacy Environments and Early Literacy Trajectories of Low-Socioeconomic Status Chilean Children. Child Dev. 2020, 91, 2042-2062. [CrossRef]

16. Berninger, V.; Abbott, R.; Cook, C.R.; Nagy, W. Relationships of attention and executive functions to oral language, reading, and writing skills and systems in middle childhood and early adolescence. J. Learn. Disabil. 2017, 50, 434-449. [CrossRef] [PubMed] 
17. Cordeiro, C.; Limpo, T.; Olive, T.; Castro, S.L. Do executive functions contribute to writing quality in beginning writers? A longitudinal study with second graders. Read. Writ. 2020, 33, 813-833. [CrossRef]

18. Fisher, R.; Myhill, D.; Twist, L. Evaluation of Every Child a Writer Report 2: Teaching and Writing in Ecaw Classes; DfE RR108b; University of Exeter and National Foundation for Educational Research: England, UK, 2011.

19. Tat, C.R. Creative Writing in Extensive Reading Instruction. J. Lit. Lang. Teach. 2021, 10, 27-36.

20. Menon, V. Positive Attitude toward Math Predicts Math Achievement in Kids. Available online: https://med.stanford.edu/ news/all-news/2018/01/positive-attitude-toward-math-predicts-math-achievement-in-kids.html (accessed on 31 August 2021).

21. Graham, S. The sciences of reading and writing must become more fully integrated. Read. Res. Q. 2020, 55, S35-S44. [CrossRef]

22. Troia, G. Evidence-Based Practices for Writing Instruction. 2014. Available online: https://ceedar.education.ufl.edu/wp-content/ uploads/2014/09/IC-5_FINAL_08-31-14.pdf (accessed on 30 November 2021).

23. Alkhamra, H.A.; Alnatour, M.M.; Abu Dahab, S.M.N.; Alabdallat, B.M. Candidates of written language disabilities among undergraduate students at the University of Jordan as perceived by students and their teachers. Int. J. Spec. Educ. 2012, 27, 27-33.

24. Hawthorne, K.A.; Bol, L.; Pribesh, S. Can providing rubrics for writing tasks improve developing writers' calibration accuracy? J. Exp. Educ. 2017, 85, 689-708. [CrossRef]

25. De Smedt, F.; Merchie, E.; Barendse, M.; Rosseel, Y.; De Naeghel, J.; Van Keer, H. Cognitive and motivational challenges in writing: Studying the relation with writing performance across students' gender and achievement level. Read. Res. Q. 2018, 53, $249-272$. [CrossRef]

26. Dunn, M.; Miller, D.; Stair, M.; Welsh-Griffin, H. Glimpses inside the minds of young writers: How children plan texts with art. J. Res. Child. Educ. 2021, 35, 503-519. [CrossRef]

27. Microsoft. OneNote. Available online: https://www.microsoft.com/en-us/microsoft-365/onenote/digital-note-taking-app (accessed on 31 August 2021).

28. Google. Google Docs. Available online: https://www.google.com/docs/about/ (accessed on 31 August 2021).

29. Google. Google Keep. Available online: https://play.google.com/store/apps/details?id=com.google.android.keep\&hl=en_US\& $\mathrm{gl}=\mathrm{US}$ (accessed on 31 August 2021).

30. Barnett, A.L.; Connelly, V.; Miller, B. The Interaction of Reading, Spelling, and Handwriting Difficulties with Writing Development. Available online: https://radar.brookes.ac.uk/radar/file/09a0bf38-c3d6-4239-aeb0-8c76dbe82b96/1/Reading\%20spelling\%20 and\%20handwriting\%20difficulties\%20-\%202019\%20-\%20Barnett\%20Connelly\%20Miller.pdf (accessed on 31 August 2021).

31. Gillespie, A.; Graham, S. A meta-analysis of writing interventions for students with learning disabilities. Except. Child. 2014, 80, 454-473. [CrossRef]

32. Rouse, A.G.; Graham, S. Best practices in writing instruction for students with learning disabilities. In Interventions in Learning Disabilities: A Handbook on Systematic Training Programs for Individuals with Learning Disabilities; Schiff, R., Joshi, R., Eds.; Springer: Berlin, Germany, 2017; pp. 175-190.

33. Flower, L.; Hayes, J.R. The cognition of discovery: Defining a rhetorical problem. Coll. Compos. Commun. 1980, $31,21-32$. [CrossRef]

34. Vygotsky, L.S. Mind in Society: The Development of Higher Psychological Processes; Harvard University Press: Cambridge, MA, USA, 1980.

35. Dockrell, J.; Arfé, B. What does the Research Say about Research/Evidence-based Intensive Intervention Programming for Writing? In Writing Instruction and Intervention for Struggling Writers: Multi-Tiered Systems of Support; Cambridge Scholars Publishing: Newcastle, UK, 2020; pp. 42-60.

36. Cindy Lin, S.J.; Monroe, B.W.; Troia, G.A. Development of writing knowledge in grades 2-8: A comparison of typically developing writers and their struggling peers. Read. Writ. Q. 2007, 23, 207-230. [CrossRef]

37. Nielsen, K. Peer and self-assessment practices for writing across the curriculum: Learner-differentiated effects on writing achievement. Educ. Rev. 2019, 73, 1-22. [CrossRef]

38. Philippakos, Z.A.T.; FitzPatrick, E. A Proposed Tiered Model of Assessment in Writing Instruction: Supporting All Student-Writers. Insights Into Learn. Disabil. 2018, 15, 149-173.

39. Crossley, S. Linguistic features in writing quality and development: An overview. J. Writ. Res. 2020, 11, 415-443. [CrossRef]

40. Latif, M.M.A. Remodeling writers' composing processes: Implications for writing assessment. Assess. Writ. 2021, $50,100547$. [CrossRef]

41. Troia, G.A.; Olinghouse, N.G.; Zhang, M.; Wilson, J.; Stewart, K.A.; Mo, Y.; Hawkins, L. Content and alignment of state writing standards and assessments as predictors of student writing achievement: An analysis of 2007 National Assessment of Educational Progress data. Read. Writ. 2018, 31, 835-864. [CrossRef]

42. Graham, S.; Harris, K.R. A component analysis of cognitive strategy instruction: Effects on learning disabled students' compositions and self-efficacy. J. Educ. Psychol. 1989, 81, 353-361. [CrossRef]

43. Deno, S.L. Developments in curriculum-based measurement. J. Spec. Educ. 2003, 37, 184-192. [CrossRef]

44. Graham, S.; Hebert, M.; Paige Sandbank, M.; Harris, K.R. Assessing the writing achievement of young struggling writers: Application of generalizability theory. Learn. Disabil. Q. 2016, 39, 72-82. [CrossRef]

45. Aull, L. Student-Centered Assessment and Online Writing Feedback: Technology in a Time of Crisis. Assess. Writ. 2020, 46, 100483. [CrossRef] 
46. Fry, E. A readability formula that saves time. J. Read. 1968, 7, 513-578. Available online: http://www.jstor.org/stable/40013635 (accessed on 31 August 2021).

47. Madnani, N.; Burstein, J.; Elliot, N.; Klebanov, B.B.; Napolitano, D.; Andreyev, S.; Schwartz, M. Writing mentor: Self-regulated writing feedback for struggling writers. In Proceedings of the 27th International Conference on Computational Linguistics: System Demonstrations, Sante Fe, NM, USA, 20-26 August 2018; pp. 113-117.

48. McCurry, D. Can machine scoring deal with broad and open writing tests as well as human readers? Assess. Writ. 2010, 15, 118-129. [CrossRef]

49. Richards, S.B. Single Subject Research: Applications in Educational Settings; Cengage: Boston, MA, USA, 2020.

50. Smarter Balanced Assessment Consortium Smarter Balanced Scoring Guide For Grades 3, 6, and 11 English/Language Arts Performance Task Full Write Baseline Sets. Available online: https:/ / portal.smarterbalanced.org/library/en/scoring-guide-forela-full-writes.pdf (accessed on 31 August 2021).

51. Smarter Balanced Validity Research. Reporting Scores. 2021. Available online: https://validity.smarterbalanced.org/scoring/ (accessed on 31 August 2021).

52. Wolfe, E.W.; Song, T.; Jiao, H. Features of difficult-to-score essays. Assess. Writ. 2016, 27, 1-10. [CrossRef]

53. Evanini, K.; Heilman, M.; Wang, X.; Blanchard, D. Automated scoring for the TOEFL Junior®Comprehensive writing and speaking test. ETS Res. Rep. Ser. 2015, 2015, 1-11. [CrossRef]

54. Mantei, J.; Kervin, L. Teacher knowledge and student learning: An examination of teacher pedagogies for the same writing topic across two consecutive grades. Aust. J. Lang. Lit. 2020, 43, 224-234.

55. Land, C.L. Recentering Purpose and Audience as Part of a Critical, Humanizing Approach to Writing Instruction. Read. Res. Q. 2020. Available online: https:/ /ila.onlinelibrary.wiley.com/doi/10.1002/rrq.371 (accessed on 31 August 2021).

56. Hauck, D. The Effect of Small Group, Supplemental Phonics and Phonemic Awareness Intervention on Struggling Readers' Foundational Literacy Skills. Ph.D. Thesis, The William Paterson University of New Jersey, Wayne, NJ, USA, 2021.

57. Hunt, S. Increasing Reading Comprehension in Struggling Second Grade Students Using Targeted Strategies. 2021. Available online: https: / / mdsoar.org/handle/11603/21482 (accessed on 31 October 2021).

58. Hoekstra, N.J. Providing access to text for diverse students with the Epub3 format. Teach. Except. Child. 2021. [CrossRef]

59. Merga, M.K.; Roni, S.M. The influence of access to eReaders, computers and mobile phones on children's book reading frequency. Comput. Educ. 2017, 109, 187-196. [CrossRef]

60. Graham, S.; McKeown, D.; Kiuhara, S.; Harris, K.R. A meta-analysis of writing instruction for students in the elementary grades. J. Educ. Psychol. 2012, 104, 879. [CrossRef]

61. Englert, C.S.; Raphael, T.E. Developing successful writers through cognitive strategy instruction. In Advances in Research on Teaching; Brophy, J.E., Ed.; JAI Press: Greenwich, CT, USA, 1989; Volume 1, pp. 105-153.

62. Raphael, T.E.; Englert, C.S. Writing and reading: Partners in constructing meaning. Read. Teach. 1990, 43, 388-400.

63. Englert, C.S.; Thomas, C.C. Sensitivity to text structure in reading and writing: A comparison between learning disabled and non-learning disabled students. Learn. Disabil. Q. 1987, 10, 93-105. [CrossRef]

64. Meyer, B.J.F. The Organization of Prose and Its Effects on Memory; North-Holland: Amsterdam, The Netherlands, 1975.

65. Yoo, M.S. Students' Perceived and Actual Use of Strategies for Reading and Writing; University of California: Berkeley, CA, USA, 2010. Available online: https:/ / escholarship.org/content/qt6gx43299/qt6gx43299_noSplash_b81df2891b68dcc890046c29bbd75a8c.pdf (accessed on 3 December 2021).

66. Dias, L.; Victor, A. Teaching and learning with mobile devices in the 21st century digital world: Benefits and challenges. Eur. J. Multidiscip. Stud. 2017, 2, 339-344. Available online: https://www.researchgate.net/profile/Mohd-Azmir-Mohd-Nizah/ publication/317673149_The_Political_Tolerance_and_the_Youth_Perceived_Participation_in_Malaysia/links/59488bf40f7e9b1 d9b233588/The-Political-Tolerance-and-the-Youth-Perceived-Participation-in-Malaysia.pdf\#page=97 (accessed on 22 November 2021). [CrossRef]

67. Dunn, M.; Albagshi, A.; Aldawsari, F. Investigating writing instruction practices with technology for students with deafness and hearing loss. Lang. Lit., Accepted for publication.

68. Williams, C.; Beam, S. Technology and writing: Review of research. Comput. Educ. 2019, 128, 227-242. [CrossRef] 